\title{
Influence of bean rhizosphere on the biological properties and phosphorus fractionation in the calcareous soils amended with municipal sewage sludge
}

\author{
Tahereh RAIESI $^{1^{*}}$, Alireza HOSSEINPUR ${ }^{2}$, Hamideh RAIESI $^{3}$ \\ ${ }^{1}$ Horticultural Science Research Institute, Citrus and Subtropical Fruit Research Center, Agricultural Research and Education \\ Organization (AREO), Ramsar 46915, Iran; \\ ${ }^{2}$ Department of Soil Science, College of Agriculture, Shahrekord University, Shahrekord 88186, Iran; \\ ${ }^{3}$ Department of Plant Protection, College of Agriculture, Guilan University, Guilan 41635, Iran
}

\begin{abstract}
The biological and chemical conditions of the rhizosphere are known to considerably differ from those of the bulk soil, as a consequence of a range of processes that are induced either directly by the activity of plant roots or indirectly by the stimulation of microbial population and activity in the rhizosphere. Information about phosphorus $(P)$ fractionation in the rhizosphere soils amended with municipal sewage sludge (MSS) is limited. were We carried out greenhouse experiments using a rhizobox in order to evaluate the effects of bean rhizosphere on the various inorganic $P(P i)$ fractions, organic $P(P o), P$ in particulate fraction (PF-P), Olsen- $P$, dissolved organic $C$ (DOC), microbial biomass $P$ (MBP) and alkaline phosphatase (ALP) enzyme in 10 calcareous soils amended with MSS (10 g MSS was added to $1 \mathrm{~kg}$ soil). Non-occluded $\mathrm{P}$, occluded $\mathrm{P}$, calcium phosphate and residual $\mathrm{P}$ were also quantitated. The results showed that DOC, MBP and ALP activity strongly increased and PF-P and Olsen-P decreased in the rhizosphere soils compared with in the bulk soils $(P<0.05)$. The contents of non-occluded $\mathrm{P}$, occluded $P$ and residual-P fractions in the rhizosphere soils were lower than in the bulk soils, while the contents of calcium phosphate and organic $\mathrm{P}$ in the rhizosphere soils were higher than in the bulk soils. Simple correlation coefficients showed that $P$ uptake had positive relationship with non-occluded $P$, occluded $P$, calcium phosphate fractions and PF-P in the rhizosphere soils. The results suggest that the short-term application of MSS to the calcareous soils may increase Po and calcium phosphate fractions in the rhizosphere soils, and calcium phosphate fraction is potentially available to crops.
\end{abstract}

Keywords: biological properties; mineral phosphorus; organic phosphorus; semi-arid land

Citation: Tahereh RAIESI, Alireza HOSSEINPUR, Hamideh RAIESI. 2015. Influence of bean rhizosphere on the biological properties and phosphorus fractionation in the calcareous soils amended with municipal sewage sludge. Journal of Arid Land, 7(5): 644-652. doi: 10.1007/s40333-015-0010-7

The rhizosphere is defined as that soil affected by the presence of the roots of growing plants (Uren, 2007). Soil processes at the rhizosphere affect the mineral nutrition of plants (Nuruzzaman et al., 2006; Zhao and $\mathrm{Wu}, 2014)$. Phosphorus (P) is one of primary limitation for plant growth in arid and semi-arid soils due to the low concentration of $\mathrm{P}$ in the soil solution (0.1$1.0 \mathrm{mg} / \mathrm{L}$; Larsen, 1967). Phosphorus in the soil is present in the inorganic $\mathrm{P}(\mathrm{Pi})$ and organic $\mathrm{P}(\mathrm{Po})$ forms, but its Po form, which constitutes $20 \%$ to $80 \%$ of total $\mathrm{P}$, is inert (Larsen, 1967). Organic $\mathrm{P}$ can be an important source for plant growth, but it has to be mineralized into Pi by phosphatase enzymes before it can be taken up by plants (Anderson, 1980). The evidences showed that phosphatase activity in the rhizosphere soils of the most plants is higher than in the bulk soils (Chen et al., 2002; Chen, 2003; Balík et al., 2007; Wang et al., 2008; Waldrip-Dail et al., 2011; Maltais-Landry et al., 2014; Ye et al., 2015). A recently proposed estimator of $\mathrm{P}$ mineralization

*Corresponding author: Tahereh RAIESI (E-mail: taraiesi@gmail.com)

Received 2015-01-06; revised 2015-05-18; accepted 2015-05-20

(C) Xinjiang Institute of Ecology and Geography, Chinese Academy of Sciences, Science Press and Springer-Verlag Berlin Heidelberg 2015 
potential is the total $\mathrm{P}$ content in the particulate fraction (PF) (Ciampitti et al., 2011). The PF is composed by those particles whose sizes are $>53 \mu \mathrm{m}$ and includes sands and partially decomposed animal and plant residues (Cambardella and Elliott, 1992). This fraction has a high response to management practices and significantly contributes to nutrients dynamic (Janzen et al., 1998).

Crop plants can only take up available $\mathrm{P}$, but other fractions of $\mathrm{P}$, such as $\mathrm{NaOH}$-extracted $\mathrm{P}$ and acid-extracted $\mathrm{P}$ are depleted due to crop growth (Saleque et al., 2004). Sequential extraction procedures for inorganic $\mathrm{P}$ use various chemical reagents to selectively solubilize the $\mathrm{Al}, \mathrm{Fe}$, or $\mathrm{Ca}$ phosphate phases (Harrell and Wang, 2007). The traditional Chang and Jackson's (1957) scheme as modified by Olsen and Sommers (1982) provides a relatively effective approximation to major $\mathrm{P}$ forms in calcareous soils. Other fraction schemes may be more useful with acid soils (Hedly et al., 1982). The Olsen and Sommers (1982) fraction scheme has been widely used for investigating the forms and transformation of $\mathrm{P}$ in the calcareous soils (Delgado et al., 2000; Ahmad et al., 2006; Harel and Wang, 2007). Soil P fractions procedures can assist in determining the shift in $\mathrm{P}$ fractions in the rhizosphere. Fractionation procedures can identify $\mathrm{P}$ fractions that are sources and sinks of plant available $\mathrm{P}$ during growing season (Shaheen et al., 2007). Nurozanan et al. (2006) and Wang et al. (2008) found that bicarbonate and hydroxide-extractable $\mathrm{P}$ fractions were considerable sources of $\mathrm{P}$ for all P-stressed plant under acid conditions. In addition, $\mathrm{Vu}$ et al. (2008) and Rose et al. (2010) found that residual-P fraction was an important source of $\mathrm{P}$ for all plant under alkaline conditions.

The importance of maintaining an adequate $\mathrm{P}$ supply to crops for maximizing agricultural output has long been recognized and the routine application of $\mathrm{P}$ fertilizers to agricultural land has become an integral part of agriculture in developed countries (Withers et al., 2001). Municipal sewage sludge (MSS) has been increasingly used in numerous countries around the world as a well known reusable source of $\mathrm{P}$, nitrogen (N) and other macro- and micro-nutrients (Smith, 1996; Islas-Espinoza et al., 2014). Availability of P following application of MSS can be influenced by microbial and chemical properties of the soil, MSS composition and rhizosphere processes.

Little quantitative information is available for status of $\mathrm{P}$ fractions and their depletion in the rhizosphere of bean plant growing in soils amended with MSS. Therefore, the objectives of this research were: 1) to compare some biological properties, particulate fraction (PF-P), Olsen-P, Pi fractionations and Po in the bean rhizosphere and the bulk soils amended with MSS; and 2) to evaluate the correlations between plant indices with $\mathrm{P}$ fractions in 10 calcareous soils amended with MSS.

\section{Materials and methods}

\subsection{Soil materials}

Ten surface soil samples $(0-30 \mathrm{~cm})$ were collected from Chaharmahal-Va-Bakhtiari province, in the central Iran. The fields were under a bean (Phaseolus vulgaris L.) and wheat (Triticum aestivum L.) rotation. Particle-size distribution was determined by the hydrometer method (Gee and Bauder, 1986). Electrical conductivity (EC) was determined in soil-to-water ratio (1:2) by conductivity meter (Rhoades, 1996) and $\mathrm{pH}$ was measured in a soil-to-water suspension ratio of 1:2 (Thomas, 1996). Organic carbon (OC) was determined by wet oxidation (Nelson and Sommers, 1996), equivalent calcium carbonate was determined by titration (Loeppert and Suarez, 1996), and cation exchange capacity (CEC) was determined using the method of Sumner and Miller (1996). Available P was determined using 0.5 $\mathrm{M} \mathrm{NaHCO}_{3}$ (Kuo, 1996).

Municipal sewage sludge was used from the refinery of Shahrekord city, central Iran. Aerobically digested sewage sludge (activated sludge) samples were air dried, sieved $(<1 \mathrm{~mm})$ and analyzed for some chemical characteristics. Properties of MSS such as $\mathrm{pH}$ (sludge to water suspension ratio of 1:5) (Thomas, 1996) and EC (1:5, sludge to water) (Rhoades, 1996) were determined. Total $\mathrm{P}$ contents were determined after digestion of samples in a nitric acid and perchloric acid mixture (Kuo, 1996). Total $\mathrm{N}$ was determined using the Kjeldahl method (Bremner, 1996). Total zinc $(\mathrm{Zn})$, copper $(\mathrm{Cu})$, cadmium $(\mathrm{Cd})$ and lead $(\mathrm{Pb})$ 
were measured (Sposito et al., 1982) as well.

\subsection{Greenhouse experiment}

Air dried and sieved $(<2 \mathrm{~mm})$ soils samples $(4 \mathrm{~kg})$ were mixed thoroughly with MSS at rates equivalent to 10 -g air-dried sludge per $\mathrm{kg}$ soil, which was equivalent to an approximate field rate of $39 \mathrm{mg}$ dried sludge per $\mathrm{hm}^{2}$ at a soil depth of $0-30 \mathrm{~cm}$. The soil samples were incubated in triplicate at $70 \%$ field capacity moisture level at $20^{\circ} \mathrm{C} \pm 3^{\circ} \mathrm{C}$ for a period of 30 days. In this study, rhizosphere properties were studied using a rhizobox. The dimension of the rhizobox was $180 \mathrm{~mm} \times 132 \mathrm{~mm} \times 160 \mathrm{~mm}$ (length $\times$ width $\times$ height). The rhizobox had three compartments of central compartment or rhizosphere zone (32-mm in length), surrounded by nylon cloth $(24 \mu \mathrm{m})$, and left and right non-rhizosphere zones $(50-\mathrm{mm}$ in length; Fig. 1). Therefore, the soil sample was divided into three compartments by a polyester cloth impenetrable to roots. The central compartment, which considered as rhizosphere soil, was filled with 1-kg soil, while the other compartments were filled with 3-kg air-dried soils. Bean seeds were surface sterilized in $1 \%$ sodium hypochlorite for $3 \mathrm{~min}$ and rinsed thoroughly in distilled water. Six seeds were planted in the central compartment of each rhizobox after inoculation with rhizobium. After germination, seedlings were thinned to four plants per rhizobox. Plants were grown in the greenhouse with natural light at $20^{\circ} \mathrm{C} \pm 3^{\circ} \mathrm{C}$. The plants were harvested at the end of 50 days after germination.

Plant samples were separated into shoots and roots, oven dried at $65^{\circ} \mathrm{C}$ for $72 \mathrm{~h}$. Dried shoots were ground for $\mathrm{P}$ analysis. Phosphorus concentration in plant digests was determined calorimetrically by the ascorbic

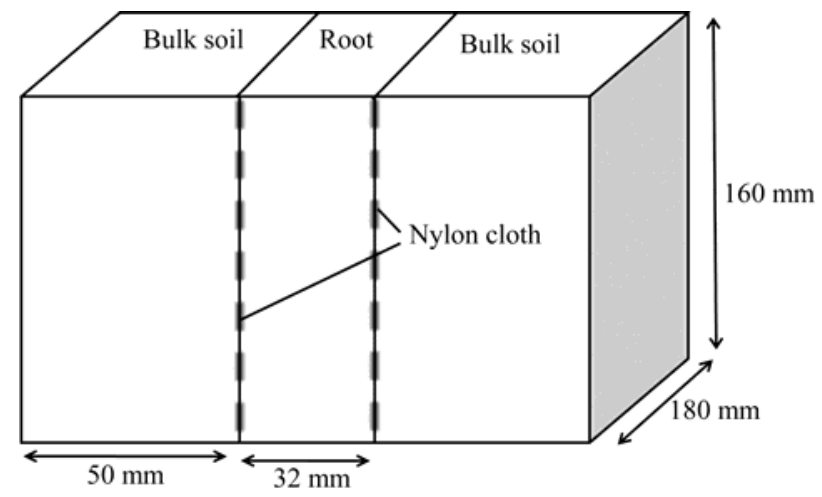

Fig. 1 The scheme of rhizobox using in present research acid method (Murphy and Riley, 1962). Rhizoboxes were then dismantled. The soil that tightly adhered to the root surfaces in the central compartment of each rhizobox, and the root-free soil that was taken from the soil 4-5 cm away from both sides of the nylon cloths were recognized as the rhizosphere and the bulk soils, respectively. A subsample of each rhizosphere soil and corresponding bulk soil were stored in $4^{\circ} \mathrm{C}$ to assay biological properties. The remaining soils were air dried and used for organic $\mathrm{P}$, available $\mathrm{P}$ and mineral $\mathrm{P}$ fractionation determination. Dissolved organic $\mathrm{C}$ (DOC) was measured by dichromate oxidation method (Nelson and Summers, 1996). Microbial biomass P (MBP) was determined using the method of Brooks et al. (1982). Alkaline phosphatase (ALP) activities were determined using the method of Tabatabaei and Bremner (1996). Organic P was determined by ignition methods (Kuo, 1996). Available P in soils was determined using the Olsen method (Kuo, 1996). Soil samples were fractioned using the method proposed by Cambardella and Eliott (1992), but replacing the $0.05 \mathrm{M}$ sodium hexamethaphosphate $\left[\left(\mathrm{NaPO}_{3}\right)_{6}\right]$ solution by a $1 \mathrm{M}$ sodium chloride $(\mathrm{NaCl})$ solution as dispersing agent, to avoid the addition of $\mathrm{P}$ (Wyngaard et al., 2013). The fraction that remained over the $53-\mu \mathrm{m}$ sieve was considered as PF. In the PF, the contents of total $\mathrm{P}$ were measured after digestion of samples in a nitric acid and perchloric acid mixture (Kuo, 1996). A sequential fractionation procedure described by Olsen and Sommers (1982) was modified and used for characterizing different forms of inorganic $\mathrm{P}$ in the rhizosphere and the bulk soils. The method was slightly modified from the original version by adding a complete digestion at the end for residual $\mathrm{P}$ (Table 1). Phosphorus concentrations in extracts were determined by the ascorbic acid method (Murphy and Riley, 1962).

\subsection{Statistical analysis}

The experiment was set up in a completely randomized design. All data were represented as means of three replicates. The effects of soil and environment (rhizosphere and bulk) over P fractions, chemical and biological properties were evaluated using Statistica 10.0 software. The effects were considered statistically 
Table 1 Sequential $P$ fraction methodology and resulting targeted $P$ forms released during the chemical $P$ fractionation procedure

\begin{tabular}{|c|c|c|c|}
\hline Fraction & Extractant & Equilibration & Targeted $\mathrm{P}$ forms \\
\hline $\begin{array}{l}\text { Aluminium and } \\
\text { iron-bound } \mathrm{Pi}\end{array}$ & $\begin{array}{l}0.1 \mathrm{~N} \text { sodium hydroxide }+1 \mathrm{M} \\
\text { sodium chloride }\end{array}$ & $17 \mathrm{~h}$ & $\begin{array}{l}\text { Phosphate adsorbed on mineral surfaces, phosphate released by } \\
\text { the hydrolysis of Fe and Al and by the hydrolysis of Fe and Al } \\
\text { complexes (Chang and Jackson, 1957; Delgado and Torrent, } \\
\text { 2000) }\end{array}$ \\
\hline Re-adsorbed P & $\begin{array}{l}0.3 \mathrm{M} \text { sodium citrate }+1 \mathrm{M} \\
\text { sodium bicarbonate }\end{array}$ & $15 \mathrm{~min}$ at $85^{\circ} \mathrm{C}$ & $\begin{array}{l}\text { Phosphate re-adsorbed to carbonate surfaces during the preced- } \\
\text { ing sodium hydroxide extraction; also, the labile pedogenic } \\
\text { Ca-rich phosphates were extracted (Williams et al., 1971; Del- } \\
\text { gado and Torrent, 2000) }\end{array}$ \\
\hline Occluded P & $\begin{array}{l}0.3 \mathrm{M} \text { sodium citrate }+1 \mathrm{M} \\
\text { sodium bicarbonate }+ \text { sodium } \\
\text { dithionite }(1 \mathrm{~g})\end{array}$ & $\begin{array}{l}\text { Preheat } 15 \text { min at } 85^{\circ} \mathrm{C} \text { after } \\
\text { sodium citrate+sodium } \\
\text { bicarbonate addition; additional } \\
15 \text { min after dithionite addition }\end{array}$ & $\begin{array}{l}\text { Reductant-soluble } \mathrm{P} \text {, mostly occluded in Fe oxides; this fraction } \\
\text { may also include a small portion of labile Ca-P not removed in } \\
\text { the previous citrate bicarbonate extraction (Chang and Jackson, } \\
\text { 1957; Williams et al., 1971) }\end{array}$ \\
\hline $\begin{array}{l}\text { Calcium } \\
\text { phosphates }\end{array}$ & $1 \mathrm{~N}$ hydrochloric acid & $1 \mathrm{~h}$ & $\begin{array}{l}\text { Stable calcium phosphates, including lithogenic apatite but } \\
\text { excluding more labile Ca-P forms removed in the previous cit- } \\
\text { rate bicarbonate and citrate bicarbonate dithionate fractions } \\
\text { (Chang and Jackson, 1957; Delgado et al., 2000) }\end{array}$ \\
\hline Residual P & $\begin{array}{l}\text { Concentration nitric acid; } \\
\text { concentration hydrofluoric } \\
\text { acid } 70 \% \text { digestion is accom- } \\
\text { plished }\end{array}$ & Variable until complete & Most chemically stable inorganic and organic $\mathrm{P}$ forms \\
\hline
\end{tabular}

Note: The re-adsorbed $\mathrm{P}$ combined with the aluminum and iron bound inorganic $\mathrm{P}(\mathrm{Pi})$ was correctly estimated as non-occluded.

significant at $P<0.05$ level. The least significant difference (LSD) test was used to compare treatments means. The Spearman's correlation was used to evaluate relationship between variables.

\section{Results and discussion}

\subsection{Solid sewage sludge}

The $\mathrm{pH}$ was 7 in the used MSS and the EC was 2.25 $\mathrm{dS} / \mathrm{m}$. The $\mathrm{N}$ and $\mathrm{P}$ contents in air-dried MSS were 15.4 and $18.5 \mathrm{~g} / \mathrm{kg}$. The amounts of total $\mathrm{Zn}, \mathrm{Cu}, \mathrm{Cd}$ and $\mathrm{Pb}$ in this air-dried organic source were 1,370 , $77,0.91$ and $267 \mathrm{mg} / \mathrm{kg}$, respectively.

\subsection{Physical-chemical properties of the soils}

The selected soils were slight alkaline $(\mathrm{pH}=7.9-8.1)$ and non-saline $(\mathrm{EC}=0.26-0.61 \mathrm{dS} / \mathrm{m})$. Clay content ranged from 133 to $550 \mathrm{~g} / \mathrm{kg}$. Sand content ranged from 50 to $617 \mathrm{~g} / \mathrm{kg}$. The CEC ranged from 10.3 to $33.3 \mathrm{cmol}_{+} / \mathrm{kg}$. Organic carbon contents ranged from 3.1 to $13.9 \mathrm{~g} / \mathrm{kg}$. The equivalent $\mathrm{CaCO}_{3}$ ranged from 162 to $475 \mathrm{~g} / \mathrm{kg}$. Olsen P ranged from 16 to $72 \mathrm{mg} / \mathrm{kg}$ (Table 2).

\subsection{Biological and chemical properties}

The effects of soil types, environment and environment $\times$ soil over Olsen-P, PF-P, MBP and ALP were significant (Table 3 ). Irrespective of soil type, the

Table 2 Physical-chemical properties of the studied soils

\begin{tabular}{|c|c|c|c|c|c|c|c|c|c|c|}
\hline \multirow{2}{*}{ Soil No. } & \multirow{2}{*}{ Soil classification } & \multirow{2}{*}{ Soil texture } & Clay & Sand & $\mathrm{CaCO}_{3}$ & Organic carbon & \multirow{2}{*}{$\mathrm{pH}$} & \multirow{2}{*}{$\begin{array}{c}\mathrm{EC} \\
(\mathrm{dS} / \mathrm{m})\end{array}$} & \multirow{2}{*}{$\begin{array}{c}\mathrm{CEC} \\
\left(\mathrm{cmol}_{+} / \mathrm{kg}\right)\end{array}$} & \multirow{2}{*}{$\begin{array}{l}\text { Olsen-P } \\
(\mathrm{mg} / \mathrm{kg})\end{array}$} \\
\hline & & & & & $(\mathrm{g} / \mathrm{kg})$ & & & & & \\
\hline 1 & Typic Haploxerepts & Clay loam & 370 & 277 & 421 & 3.1 & 8.0 & 0.36 & 14.2 & 24.7 \\
\hline 2 & Typic Haploxerepts & Clay & 476 & 126 & 162 & 5.0 & 8.0 & 0.38 & 23.7 & 15.9 \\
\hline 3 & Typic Haploxeralfs & Loam & 250 & 416 & 410 & 4.3 & 8.0 & 0.46 & 10.3 & 17.5 \\
\hline 4 & Typic Haploxerepts & Clay & 494 & 143 & 475 & 4.1 & 8.0 & 0.42 & 12.4 & 19.1 \\
\hline 5 & Typic Calcixerpts & Silty clay & 523 & 50 & 388 & 5.4 & 8.0 & 0.46 & 29.4 & 18.1 \\
\hline 6 & Typic Haploxerepts & Clay & 550 & 147 & 267 & 8.4 & 7.9 & 0.59 & 33.3 & 22.4 \\
\hline 7 & Typic Haploxerepts & Silty clay loam & 371 & 189 & 325 & 5.1 & 8.1 & 0.36 & 16.3 & 40.1 \\
\hline 8 & Typic Calcixerpts & Clay & 490 & 117 & 266 & 13.9 & 8.1 & 0.59 & 25.9 & 32.0 \\
\hline 9 & Typic Calcixerpts & Silty clay loam & 370 & 162 & 210 & 10.4 & 8.0 & 0.61 & 18.9 & 71.9 \\
\hline 10 & Typic Haploxerepts & Sandy loam & 133 & 617 & 190 & 7.0 & 8.0 & 0.26 & 10.3 & 16.8 \\
\hline
\end{tabular}

Note. EC: electrical conductivity; CEC: cation exchange capacity 
Table 3 Effects of root activity (rhizosphere and bulk soils) on chemical and biological properties

\begin{tabular}{|c|c|c|c|c|c|c|c|c|c|c|}
\hline \multirow{3}{*}{ Soil No. } & \multirow{2}{*}{\multicolumn{2}{|c|}{$\frac{\text { Olsen-P }}{(\mathrm{mg} \mathrm{P} / \mathrm{kg})}$}} & \multirow{2}{*}{\multicolumn{2}{|c|}{$\frac{\text { Dissolved organic } \mathrm{C}}{(\mathrm{mg} \mathrm{C} / \mathrm{kg})}$}} & \multirow{2}{*}{\multicolumn{2}{|c|}{$\frac{\text { Microbial biomass } \mathrm{P}}{(\mathrm{mg} \mathrm{P} / \mathrm{kg})}$}} & \multirow{2}{*}{\multicolumn{2}{|c|}{$\frac{\mathrm{P} \text { in particulate fraction }}{(\mathrm{mg} \mathrm{P} / \mathrm{kg})}$}} & \multirow{2}{*}{\multicolumn{2}{|c|}{$\frac{\text { Alkaline phosphatase }}{(\mu \mathrm{g} \text { PNP } /(\mathrm{g} \cdot h))}$}} \\
\hline & & & & & & & & & & \\
\hline & Rhizosphere & Bulk & Rhizosphere & Bulk & Rhizosphere & Bulk & Rhizosphere & Bulk & Rhizosphere & Bulk \\
\hline 1 & 34 & 45 & 87 & 56 & 17.9 & 4.3 & 9.4 & 13.8 & 99 & 44 \\
\hline 2 & 33 & 40 & 105 & 78 & 17.4 & 6.6 & 6.8 & 9.1 & 84 & 70 \\
\hline 3 & 32 & 36 & 78 & 68 & 25.2 & 5.7 & 7.2 & 11.6 & 95 & 49 \\
\hline 4 & 42 & 46 & 105 & 88 & 8.9 & 6.7 & 2.0 & 2.5 & 83 & 65 \\
\hline 5 & 39 & 47 & 115 & 107 & 12.6 & 9.2 & 6.6 & 8.4 & 109 & 81 \\
\hline 6 & 40 & 47 & 104 & 95 & 10.8 & 6.3 & 12.9 & 15.9 & 114 & 107 \\
\hline 7 & 52 & 63 & 114 & 91 & 8.9 & 6.1 & 12.7 & 15.3 & 136 & 105 \\
\hline 8 & 42 & 52 & 110 & 82 & 20.0 & 13.3 & 12.5 & 18.2 & 148 & 102 \\
\hline 9 & 94 & 127 & 116 & 86 & 39.2 & 17.3 & 18.7 & 28.3 & 137 & 89 \\
\hline \multirow[t]{2}{*}{10} & 39 & 40 & 67 & 56 & 11.6 & 8.3 & 3.4 & 3.5 & 99 & 94 \\
\hline & $P$ value & LSD & $P$ value & LSD & $P$ value & LSD & $P$ value & LSD & $P$ value & LSD \\
\hline Soil & $<0.01$ & 5 & $<0.01$ & 14 & $<0.01$ & 2.0 & $<0.01$ & 1.9 & $<0.01$ & 15 \\
\hline Environment & $<0.01$ & 2 & $<0.01$ & 6 & $<0.01$ & 0.9 & $<0.01$ & 0.8 & $<0.01$ & 7 \\
\hline $\begin{array}{c}\text { Soil× } \\
\text { environment }\end{array}$ & $<0.01$ & 7 & 0.61 & 19 & $<0.01$ & 2.8 & $<0.01$ & 2.6 & $<0.01$ & 22 \\
\hline
\end{tabular}

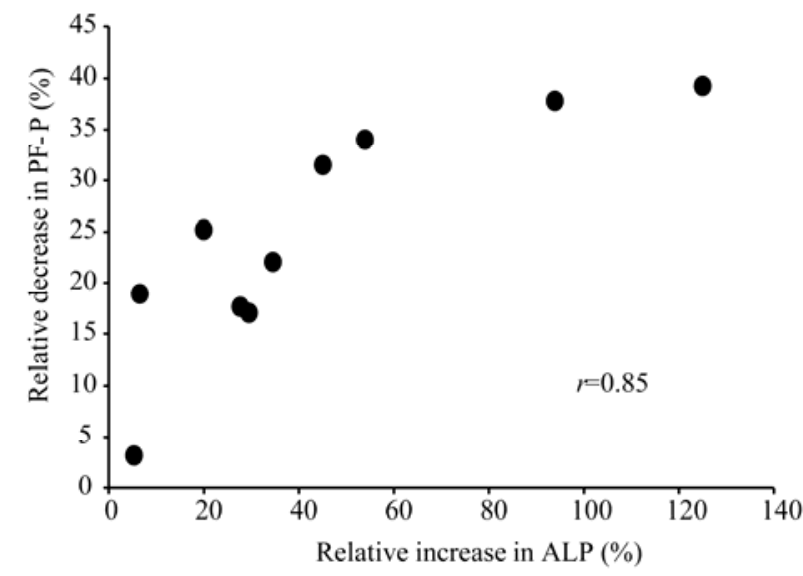

Fig. 2 Relationship between depletion percentage of $P$ in the particulate fraction (PF-P) and increase percentage of alkaline phosphatase (ALP)

contents of Olsen-P in the rhizosphere $(45 \mathrm{mg} / \mathrm{kg}$ ) were lower than those in the bulk $(54 \mathrm{mg} / \mathrm{kg})$ soils due to the $\mathrm{P}$ uptake by plant and microorganisms. The DOC averaged 100 and $81 \mathrm{mg} \mathrm{C} / \mathrm{kg}$ in the rhizosphere and bulk soils, respectively. And the MBP averaged 17.3 and $8.4 \mathrm{mg} \mathrm{P} / \mathrm{kg}$ in the rhizosphere and bulk soils, respectively. Alkaline phosphatase activity averaged 110 and $81 \mu \mathrm{g} \mathrm{PNP} /(\mathrm{g} \cdot \mathrm{h})$ in the rhizosphere and bulk soils, respectively, which confirmed a higher microbial activity in the rhizosphere soils caused by a higher content of easily degradable root exudates (Table 3 ).
Phosphatase enzyme activity strongly increased in the rhizosphere soils compared with the bulk soils $(P<0.05)$, suggesting that Po may be contribute to $P$ release in the rhizosphere soil. Irrespective of soil type, there was a significant $(P<0.01)$ decrease in PF-P in the rhizosphere. The results have also provided ample evidence of a close relationship between depletion percentage of PF-P and increased percentage of ALP (Fig. 2). The evidence showed that phosphatase activity in the rhizosphere soils of the most plants was higher than in the bulk soils (Nuruzzaman et al., 2006; Balík et al., 2007; Wang et al., 2008; Ye et al., 2015).

\subsection{Phosphorus fractionation}

The effects of soil types, environment and environment $\times$ soil over all fractions were significant (Table 4). Non-occluded P represents $\mathrm{Fe}$ and Al-bound P and re-adsorbed to carbonate surfaces during the preceding sodium hydroxide extraction, which is available to plants less than labile P (Olsen-P). Irrespective of soil type, the contents of non-occluded $\mathrm{P}$ in the rhizosphere $(90 \mathrm{mg} / \mathrm{kg}$ ) were lower than those in the bulk (95 $\mathrm{mg} / \mathrm{kg}$ ) soils. The occluded $\mathrm{P}$ is the fraction trapped within $\mathrm{Fe}$ and $\mathrm{Al}$ oxides matrices and it is less available to plant than the labile $\mathrm{P}$, non-occluded $\mathrm{P}$. The contents of occluded $P$ averaged 61 and $67 \mathrm{mg} / \mathrm{kg}$ in the rhizosphere and bulk soils, respectively. Regard- 
Table 4 Effects of root activity (rhizosphere and bulk soils) on various $\mathrm{P}$ fractions (mg P/kg)

\begin{tabular}{|c|c|c|c|c|c|c|c|c|c|c|}
\hline \multirow[t]{2}{*}{ Soil No. } & \multicolumn{2}{|c|}{ Non-occluded P } & \multicolumn{2}{|c|}{ Occluded P } & \multicolumn{2}{|c|}{ Calcium P } & \multicolumn{2}{|c|}{ Residual P } & \multicolumn{2}{|c|}{ Organic $\mathrm{P}$} \\
\hline & Rhizosphere & Bulk & Rhizosphere & Bulk & Rhizosphere & Bulk & Rhizosphere & Bulk & Rhizosphere & Bulk \\
\hline 1 & 88 & 88 & 47 & 54 & 440 & 412 & 116 & 190 & 86 & 44 \\
\hline 2 & 61 & 73 & 52 & 62 & 497 & 543 & 180 & 156 & 72 & 39 \\
\hline 3 & 81 & 84 & 54 & 46 & 524 & 492 & 137 & 225 & 84 & 49 \\
\hline 4 & 76 & 86 & 47 & 48 & 315 & 243 & 108 & 210 & 63 & 58 \\
\hline 5 & 73 & 77 & 24 & 36 & 503 & 509 & 230 & 183 & 63 & 48 \\
\hline 6 & 66 & 78 & 53 & 67 & 387 & 347 & 244 & 303 & 108 & 71 \\
\hline 7 & 95 & 105 & 87 & 91 & 815 & 739 & 201 & 325 & 93 & 77 \\
\hline 8 & 57 & 63 & 83 & 94 & 393 & 392 & 185 & 218 & 153 & 98 \\
\hline 9 & 173 & 178 & 89 & 92 & 630 & 546 & 203 & 347 & 152 & 86 \\
\hline \multirow[t]{2}{*}{10} & 128 & 114 & 78 & 83 & 592 & 575 & 189 & 268 & 48 & 41 \\
\hline & $P$ value & LSD & $P$ value & LSD & $P$ value & LSD & $P$ value & LSD & $P$ value & LSD \\
\hline Soil & $<0.01$ & 9 & $<0.01$ & 7 & $<0.01$ & 27 & $<0.01$ & 10 & $<0.01$ & 12 \\
\hline Environment & $<0.01$ & 4 & $<0.01$ & 3 & $<0.01$ & 12 & $<0.01$ & 4 & $<0.01$ & 5 \\
\hline Soil×environment & 0.13 & 13 & 0.14 & 10 & $<0.01$ & 39 & $<0.01$ & 14 & $<0.01$ & 17 \\
\hline
\end{tabular}

less of soil type, the content of calcium phosphate in the bulk soil was $480 \mathrm{mg} / \mathrm{kg}$, but in the rhizosphere soil increased to $510 \mathrm{mg} / \mathrm{kg}$. The contents of organic P averaged 92 and $61 \mathrm{mg} / \mathrm{kg}$ in the rhizosphere and bulk soils, respectively. The content of residual $\mathrm{P}$ in the rhizosphere $(179 \mathrm{mg} / \mathrm{kg})$ was lower than that in the bulk soil (243 mg/kg) (Table 4). The higher concentration of organic $\mathrm{P}$ in the rhizosphere than in the bulk soils probably was because of the increasing residues in plant and animal and immobilization of inorganic $\mathrm{P}$ by microorganisms. The accumulation of organic $\mathrm{P}$ and depletion of PF in the rhizosphere soils showed that activity of bean roots had altered organic $\mathrm{P}$ fractionation.

In general, the depletion of the Pi fractions is because of plant uptake and microbial immobilization of Pi. The pattern of distribution of the Pi fractions differed between the rhizosphere and the bulk soils. In laboratory incubation studies, Waldrip-Dail et al. (2009) observed a transformation between calcium phosphate in poultry manure and labile $\mathrm{P}$ in soil. Rose et al. (2010) found that the NaOH-extractable P fraction in the alkaline soils was the one of the Pi fractions depleted by faba bean while they did not find any significant change in calcium phosphate fraction.

\subsection{The relationships between chemical and bio- logical properties and phosphorus fractions}

The correlation studies showed that DOC and MBP significantly correlated with Olsen-P in the bulk soils. Alkaline phosphatase and PF-P significantly correlated with occluded $\mathrm{P}$, residual $\mathrm{P}$ and Olsen-P in the rhizosphere and bulk soils (Table 5). This result reflected an increase in organic $\mathrm{P}$ mineralization as the activity of phosphatases increased. Inorganic P released by enzymes hydrolysis could directly accumulate in the $\mathrm{Pi}$ fractions including occluded $\mathrm{P}$, residual $\mathrm{P}$ and $\mathrm{Ol}-$ sen-P. In addition, residual $P$ fraction could be redistributed in the other fractions. Moreover, the results showed that rhizosphere PF-P was positively correlated with soil available $\mathrm{P}$, indicating that PF-P played an important role in phyto-availability of $\mathrm{P}$ in the calcareous soils amended with MSS. Chen (2003) found positive correlations between acid phosphatase activity with total, inorganic, organic and occluded $\mathrm{P}$ as well as to aluminum bound $\mathrm{P}$ and iron bound $\mathrm{P}$, whereas it was negatively related to calcium phosphate.

\subsection{Bean plant indices}

Marked differences in plant growth, $\mathrm{P}$ concentration and uptake of $\mathrm{P}$ were observed between the 10 soil samples. The shoot dry weight and $\mathrm{P}$ concentration of plants varied from 10.0 to $14.2 \mathrm{~g} /$ rhizobox and from 2,408 to $4,053 \mathrm{mg} / \mathrm{kg}$ (Table 6), respectively. Index of $\mathrm{P}$ uptake of plants growing ranged from 26 to 57 mg/rhizobox. 
Table 5 Correlation coefficients between chemical and biological properties and different $\mathrm{P}$ fractions in the rhizosphere and the bulk soils

\begin{tabular}{|c|c|c|c|c|c|}
\hline $\mathrm{P}$ fractions & Environment & Dissolved organic C & Microbial biomass $\mathrm{P}$ & Alkaline phosphate & $\mathrm{P}$ in particulate fraction \\
\hline \multirow{2}{*}{ Non-occluded P } & Rhizosphere & -0.21 & 0.05 & 0.18 & 0.19 \\
\hline & Bulk & -0.29 & -0.04 & 0.00 & 0.00 \\
\hline \multirow{2}{*}{ Occluded P } & Rhizosphere & 0.00 & 0.22 & $0.50^{* *}$ & $0.56^{* *}$ \\
\hline & Bulk & -0.02 & $0.37^{*}$ & $0.67^{* *}$ & $0.54^{* *}$ \\
\hline \multirow{2}{*}{ Calcium P } & Rhizosphere & -0.09 & 0.17 & 0.30 & 0.16 \\
\hline & Bulk & 0.03 & 0.12 & 0.14 & 0.05 \\
\hline \multirow{2}{*}{ Residual P } & Rhizosphere & 0.31 & -0.11 & $0.51^{* *}$ & $0.38^{*}$ \\
\hline & Bulk & 0.08 & 0.26 & $0.58^{* *}$ & $0.48^{* *}$ \\
\hline \multirow{2}{*}{ Olsen-P } & Rhizosphere & 0.28 & -0.13 & $0.52^{* *}$ & $0.38^{*}$ \\
\hline & Bulk & $0.42^{*}$ & $0.41^{*}$ & $0.47^{* *}$ & $0.64^{* *}$ \\
\hline
\end{tabular}

Note: ${ }^{* *}$ and ${ }^{*}$ indicate significance at $P<0.01$ and $P<0.05$ levels, respectively.

Table 6 Bean plant indices in the studied soils

\begin{tabular}{cccc}
\hline Soil No. & $\begin{array}{c}\text { Shoot weight } \\
(\mathrm{g} / \text { /hizobox })\end{array}$ & $\begin{array}{c}\text { P concentration } \\
(\mathrm{mg} / \mathrm{kg})\end{array}$ & $\begin{array}{c}\text { P uptake } \\
(\mathrm{mg} / \text { rhizobox })\end{array}$ \\
\hline 1 & 12.2 & 3,328 & 41 \\
2 & 12.7 & 2,436 & 31 \\
3 & 12.2 & 2,881 & 35 \\
4 & 10.6 & 2,408 & 26 \\
5 & 13.9 & 2,719 & 38 \\
6 & 13.6 & 2,675 & 37 \\
7 & 11.5 & 4,036 & 46 \\
8 & 10.0 & 3,289 & 33 \\
9 & 14.2 & 4,053 & 57 \\
10 & 10.8 & 3,372 & 36 \\
$P$ value & $<0.05$ & 0.06 & 0.052 \\
\hline
\end{tabular}

\subsection{The relationships between plant indices and $P$ fractions}

Correlation coefficients between plant indices and all Pi fractions were shown in Table 7. The results showed that $\mathrm{P}$ concentration was significantly correlated with non-occluded $\mathrm{P}$, occluded $\mathrm{P}$ fractions, Olsen-P and PF-P in the rhizosphere and the bulk soils and with calcium phosphate, organic $\mathrm{P}$ fraction in the rhizosphere soils. Dry weight of bean was not significantly correlated with Pi fractions. The P uptake was significantly correlated with non-occluded $\mathrm{P}$, occluded $\mathrm{P}$, calcium phosphate fractions, Olsen-P and PF-P in the rhizosphere soils and with non-occluded $\mathrm{P}$, residual P, Olsen-P and PF-P in the bulk soils. The correlations between $\mathrm{P}$ uptake and $\mathrm{P}$ fractions (except residual P) were stronger in the rhizosphere soils than the bulk soils (Table 7). In studied calcareous soils,
Table 7 Correlation coefficients between plant indices and different $\mathrm{P}$ fractions determined in the rhizosphere and the bulk soils

\begin{tabular}{llccc}
\hline P fractions & Environment & $\begin{array}{c}\text { P concen- } \\
\text { tration }\end{array}$ & $\begin{array}{c}\text { Dry } \\
\text { weight }\end{array}$ & P uptake \\
\hline Non-occluded P & Rhizosphere & $0.45^{*}$ & 0.12 & $0.39^{*}$ \\
& Bulk & $0.42^{*}$ & 0.00 & $0.39^{*}$ \\
Occluded P & Rhizosphere & $0.60^{* *}$ & -0.02 & $0.41^{*}$ \\
& Bulk & $0.55^{* *}$ & -0.09 & 0.34 \\
Calcium P & Rhizosphere & $0.45^{*}$ & 0.21 & $0.43^{*}$ \\
& Bulk & 0.32 & 0.26 & 0.36 \\
Organic P & Rhizosphere & $0.40^{*}$ & 0.18 & 0.35 \\
& Bulk & 0.28 & 0.11 & 0.27 \\
Residual P & Rhizosphere & 0.11 & 0.05 & 0.31 \\
P in particulate & Bulk & $0.50^{* *}$ & 0.07 & $0.42^{*}$ \\
fraction & Rhizosphere & $0.38^{*}$ & 0.30 & $0.48^{* *}$ \\
& Bulk & $0.55^{* *}$ & 0.34 & $0.47^{* *}$ \\
Olsen-P & Rhizosphere & $0.41^{*}$ & 0.06 & $0.37^{*}$ \\
& Bulk & $0.47^{* *}$ & 0.18 & $0.47^{* *}$ \\
\hline
\end{tabular}

Note: ${ }^{* *}$ and ${ }^{*}$ indicate significance at $P<0.01$ and $P<0.05$ levels, respectively.

therefore, soil $\mathrm{P}$ in low availability can be converted into labile $\mathrm{P}$ at greater rates in the rhizosphere of bean than in the bulk soil.

In the present study, the results showed that non-occluded $\mathrm{P}$, occluded $\mathrm{P}$ and residual $\mathrm{P}$ were depleted in the rhizosphere as compared to the bulk soil, while calcium phosphate, organic $\mathrm{P}$ were accumulated in the rhizosphere as compared to the bulk soil. Furthermore, the $\mathrm{P}$ uptake was significantly correlated with non-occluded $\mathrm{P}$, occluded $\mathrm{P}$ and calcium phosphate fractions in the rhizosphere soils (Table 7). Correlation between calcium phosphate in the rhizosphere 
and $\mathrm{P}$ uptake indicated that higher levels of calcium phosphate promoted $\mathrm{P}$ uptake and plant roots increased calcium phosphate extractability, and $\mathrm{pH}$ may influence the solubility of phosphorus fractions. Therefore, accumulation of calcium phosphate in the rhizosphere and the correlation between calcium phosphate and $\mathrm{P}$ uptake in the rhizosphere could be due to residual $\mathrm{P}$ redistribution in the other fractions including calcium phosphate. Phosphorus cycling from PF-P and its contribution to the P nutrition of agricultural crops has been well documented (Ciampitti et al., 2011). Chen (2003) indicated that the distribution pattern of $\mathrm{P}$ fractions is a result of the interactions among soil, plant root and microorganism activity. Waldrip-Dail et al. (2011) evaluated rhizosphere-induced changes in soil $\mathrm{P}$ distribution over time as affected by ryegrass growth. They found rhizosphere calcium phosphate was positively correlated to root $\mathrm{P}$ concentration and total $\mathrm{P}$ uptake at week 8, which implied that calcium phosphate had accumulated in the rhizosphere soils at week 8 .

\section{Conclusions}

The purpose of this paper was to evaluate the influence of bean rhizosphere on biological properties and phosphorus fractions in the calcareous soils amended with municipal sewage sludge. The results showed that DOC, MBP and ALP strongly increased in the rhizosphere soil compared with the bulk soil. The results of present research have also provided ample evidence of a depletion of $\mathrm{P}$ in the PF and Olsen-P in the rhizosphere soil. A close relationship between depletion percentage of PF-P and increased percentage of ALP reflect an increase in organic $\mathrm{P}$ mineralization as ALP activity increased. The results showed that the Olsen method, frequently used in the calcareous soils of Iran, had a good correlation with PF-P in the rhizosphere and the bulk soils. Therefore, the observed higher proportion of $\mathrm{P}$ in the $\mathrm{PF}$ could be an indicator of higher soil $\mathrm{P}$ availability. In addition, the pattern of distribution of the Pi fractions was differed between the rhizosphere and the bulk soils. Regardless of soil type, the results have provided ample evidence of a modification of $\mathrm{P}$ fractions in the rhizosphere soil. Simple correlation coefficients showed that $\mathrm{P}$ uptake was significantly correlated with non-occluded $\mathrm{P}$, oc- cluded $\mathrm{P}$ and calcium phosphate in the rhizosphere soils. The results indicated that occluded $\mathrm{P}$ and calcium phosphate could also act as short-term sources of plant-available $\mathrm{P}$ in addition to labile- $\mathrm{Pi}$ and non-occluded $\mathrm{P}$.

\section{Acknowledgements}

This work was supported by the Shahrekord University.

\section{References}

Ahmad W, Rahmatullah, Gill M A, et al. 2006. Bioavailability of inorganic phosphorus fractions in calcareous soils estimated by neubauer technique, iron impregnated filter paper, and chemical tests. Communications in Soil Science and Plant Analysis, 37: 1185-1193.

Anderson G. 1980. Assessing organic phosphorus in soils. In: Khasawneh F E, Sample E C, Kamprath E J. The Role of Phosphatase in Agriculture. Madison: American Society Agronomy, 411-432.

Balík J, Pavlíková D, Vaněk V, et al. 2007. The influence of long-term sewage sludge application on the activity of phosphatases in the rhizosphere of plants. Plant and Soil Environmental, 53: 375-381.

Bremner J M. 1996. Nitrogen-total. In: Sparks D L, Page A L, Helmke P A, et al. Methods of Soil Analysis: Part 3, Chemical Methods. Madison: Soil Science Society of America, 1085-1121.

Cambardella C A, Elliott E T. 1992. Particulate organic-matter changes across a grassland cultivation sequence. Soil Science Society of America Journal, 56: 777-783.

Chang S C, Jackson M L. 1957. Fractionation of soil phosphorus. Soil Science, 84: 133-144.

Chen C R, Condron L M, Davis M R, et al. 2002. Phosphorus dynamics in the rhizosphere of perennial ryegrass (Loliumperenne L.) and radiata pine (Pinus radiata D. Don.). Soil Biology and Biochemistry, 34: 487-499.

Chen H. 2003. Phosphatase activity and P fractions in soils of an 18-year-old Chinese fir (Cunninghamia lanceolata) plantation. Forest Ecology and Management, 178: 301-310.

Ciampitti I A, García F O, Picone L I, et al. 2011. Soil carbon and phosphorus pools in field crop rotations in Pampean soil of Argentina. Soil Biology and Biochemistry, 75: 616-625.

Delgado A, Ruíz J R, Del Campillo M D, et al. 2000. Calcium- and iron-related phosphorus in calcareous and calcareous marsh soils: Sequential chemical fractionation and P-31 nuclear magnetic resonance study. Communications in Soil Science and Plant Analysis, 31: 2483-2499.

Gee G W, Bauder J W. 1986. Particle size analysis. In: Klute A. Methods of Soil Analysis: Part 1, Chemical Methods. Madison: Soil Science Society of America, 404-407.

Harrel D L, Wang J J. 2007. Evaluation of three- and five-step inorganic phosphorus chemical fractionation procedures along with inductively coupled plasma determination for calcareous soils. Journal of Soil Science, 172: 55-67.

Islas-Espinoza M, Solís-Mejía L, Esteller M V. 2014. Phosphorus release 
kinetics in a soil amended with biosolids and vermicompost. Environmental Earth Sciences, 71: 1441-1451.

Janzen H H, Campbell C A. Izaurralde R C, et al. 1998. Management effects on soil C storage on the Canadian prairies. Soil and Tillage Research, 47: 181-195.

Kuo S. 1996. Phosphorus. In: Sparks D, Page A, Helmke P, et al. Methods of Soil Analysis: Part 3, Chemical Methods. Madison: Soil Science Society of America, 869-920.

Larsen S. 1967. Soil phosphorus. Advances in Agronomy, 19: 151-210. Loeppert R H, Suarez D L. 1996. Carbonate and gypsum. In: Sparks D, Page A, Helmke P, et al. Methods of Soil Analysis: Part 3, Chemical Methods. Madison: Soil Science Society of America, 437-474.

Maltais-Landry G, Scow K, Brennan E. 2014. Soil phosphorus mobilization in the rhizosphere of cover crops has little effect on phosphorus cycling in California agricultural soils. Soil Biology and Biochemistry, 78: 255-262.

Murphy J, Riley J P. 1962. A modified single solution method for the determination of phosphate in natural waters. Analytica Chimica Acta, 27: 31-36.

Nelson D W, Sommers L E. 1996. Total carbon, organic carbon, and organic matter. In: Sparks D, Page A, Helmke P, et al. Methods of Soil Analysis: Part 3, Chemical Methods. Madison: Soil Science Society of America, 961-1011

Nuruzzaman M, Lambers H, Bolland M D A, et al. 2006. Distribution of carboxylates and acid phosphatase and depletion of different phosphorus fractions in the rhizosphere of a cereal and three grain legumes. Plant and Soil, 281: 109-120.

Olsen S R, Sommers L E. 1982. Phosphorus. In: Klute A. Methods of Soil Analysis: Part 1, Chemical and Biological Property. Madison: Soil Science Society of America, 4013-4430.

Rhoades J D. 1996. Salinity: electrical conductivity and total dissolved solids. In: Sparks D, Page A, Helmke P, et al. Methods of Soil Analysis: Part 3, Chemical Methods. Madison: Soil Science Society of America, 417-435.

Rose T J, Hardiputra B, Rengel Z. 2010. Wheat, canola and grain legume access to soil phosphorus fractions differs in soils with contrasting phosphorus dynamics. Plant and Soil, 326: 159-170.

Saleque M A, Naher U A, Islam A, et al. 2004. Inorganic and organic phosphorus fertilizer effects on phosphorus fractionation in wetland rice soils. Soil Science Society of America Journal, 68: 1635-1644.

Shaheen S M, Tsadilas Ch D, Stamatiadis S. 2007. Inorganic phosphorus forms in some entisols and aridisols of Egypt. Geoderma, 142: 217-225.

Smith S R. 1996. Agricultural Recycling of Sewage Sludge and the Environment. Wallingford: CAB International, 155-206.

Sposito G, Lund L J, Chang A C. 1982. Trace metal chemistry in arid- zone field soils amended sewage sludge: I. Fractionation of $\mathrm{Ni}, \mathrm{Cu}$ $\mathrm{Zn}, \mathrm{Cd}, \mathrm{Pb}$ in solid phases. Soil Science Society of America Journal, 46: 260-264.

Sumner M E, Miller P M. 1996. Cation exchange capacity and exchange coefficient. In: Sparks D, Page A, Helmke P, et al. Methods of Soil Analysis: Part 3, Chemical Methods. Madison: Soil Science Society of America, 1201-1230.

Thomas G W. 1996. Soil pH and soil acidity. In: Sparks D, Page A, Helmke P, et al. Methods of Soil Analysis: Part 3, Chemical Methods. Madison: Soil Science Society of America, 475-490.

Ye D, Li T, Yu H, et al. 2015. P accumulation of Polygonum hydropiper, soil $\mathrm{P}$ fractions and phosphatase activity as affected by swine manure. Applied Soil Ecology, 86: 10-18.

Uren N C. 2007. Types, amounts, and possible functions of compounds released into the rhizosphere by soil-grown plants. In: Pinton R, Varanini Z, Nannipieri P. The Rhizosphere: Biochemistry and Organic Substances at the Soil-Plant Interface. New York: Taylor and Francis Publishing Group, 1-23.

Vu D T, Tang C, Armstrong R D. 2008. Changes and availability of P fractions following 65 years of $\mathrm{P}$ application in a calcareous soil in a Mediterranean region. Plant and Soil, 304: 21-33.

Waldrip-Dail H, He Z, Erich M S, et al. 2009. Soil phosphorus dynamics in response to poultry manure amendment. Soil Science, 174: 195-201.

Waldrip-Dail H M, He Z, Erich M S. 2011. Effects of poultry manure amendment on phosphorus uptake by ryegrass, soil phosphorus fractions and phosphatase activity. Biology and Fertility of Soils, 47: $407-418$.

Wang X, Tang C, Guppy C N, et al. 2008. Phosphorus acquisition characteristics of cotton (Gossypium hirsutum L.) wheat (Triticum aestivum L.) and white lupin (Lupinus albus L.) under P deficient conditions. Plant and Soil, 312: 117-128.

Williams J D H, Syers J K, Harris R F, et al. 1971. Fractionation of inorganic phosphate in calcareous lake sediments. Soil Science Society of America Journal, 35: 250-255.

Withers P J A, Edwards A C, Foy R H. 2001. Phosphorus cycling in UK agriculture and implications for phosphorus loss from soil. Soil Use and Management, 17: 139-149.

Wyngaard N, Vidaurreta A, Echeverría H E, et al. 2013. Dynamics of phosphorus and carbon in the soil particulate fraction under different management practices. Soil Science Society of America Journal, 77: $1584-1590$.

Zhao K, Wu Y. 2014. Rhizosphere calcareous soil P-extraction at the expense of organic carbon from root-exuded organic acids induced by phosphorus deficiency in several plant species. Soil Science and Plant Nutrition, 60: 640-650. 